that on the other hand his numerous mechanical devices need to be insisted upon in order to obtain an adequate idea of his varied capacity. But the result is, nevertheless, to present Hero simply as the maker of philosophic toys.

Mr. Schmidt sketches for us, but without sufficient explanation, the devices by which fountains were made to flow, and doors to open by unseen mechanical agency, but one's enthusiasm is scarcely roused though Hercules may shoot at an apple and a serpent be made to hiss his discontent with the arrangement (Fig. I). But the author does ample justice to the description of the automatic marionettes, whose behaviour and contortions afforded

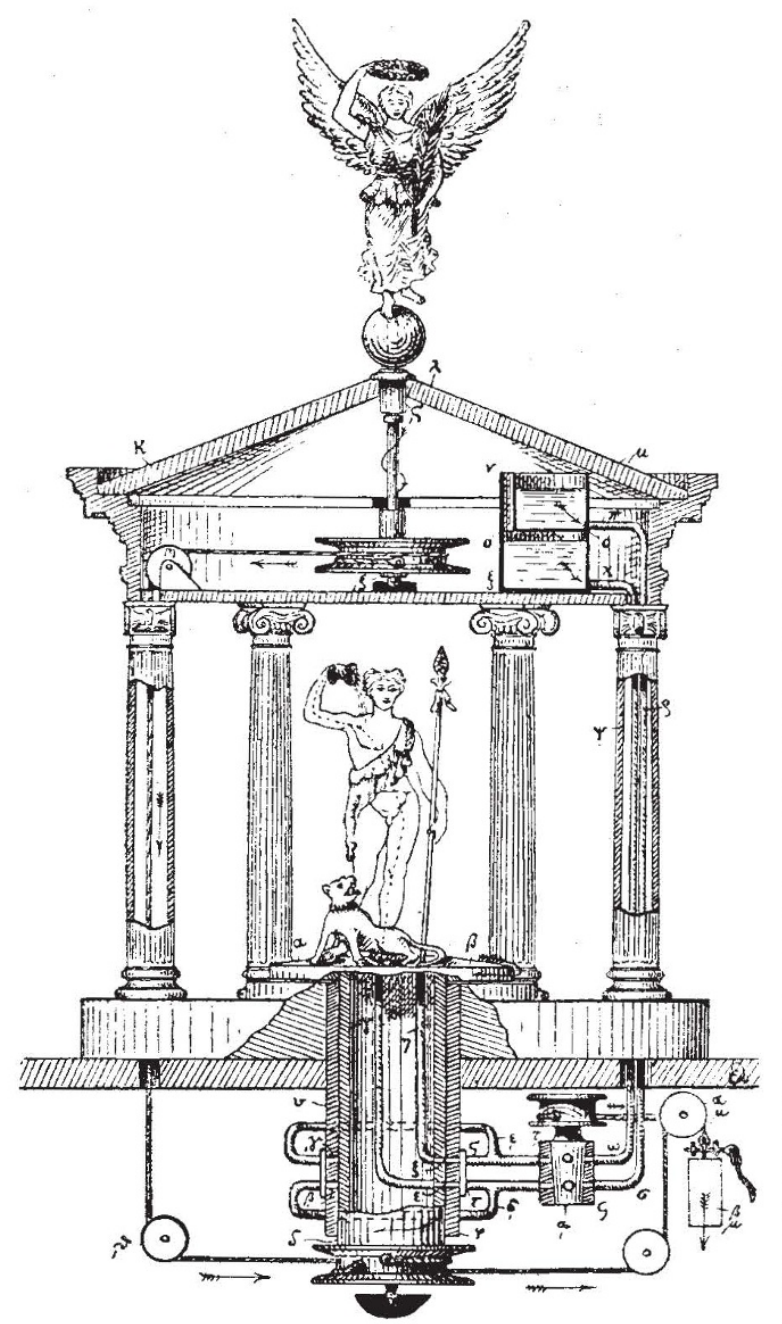

Fig. 2.-Showing the machine:y for moving the Bacchante, \&c.

sincere delight to the spectator. Two of these automatic theatres, in which some attempt at dramatic action was made, are described in detail, and we learn how the fire was suddenly kindled on the altar of Dionysius, while from the Thyrsus cup spouted respectively milk and wine, the Bacchantes urging their wild career at the same time (Fig. 2). The legend, too, of Nauplius seems to have been illustrated with great care and nicety in a succession of scenes, in which were represented the departure of the Greek ships, the rising of a storm, and the luring of the 1ll-fated Greeks by lighted torches to the dangerous promontory of Caphareus where they suffered shipwreck. All this tale is told, with the proper accompaniment of lightning and thunder, by means of moving and hidden machinery. Even Ajax is made to swim towards the land, and subsequently to perish in one of various ways according to the fancy of the stage manager. That Hero should devote himself to the construction of the necessary tricks, required to reproduce these scenes, when he seemed clearly capable of higher intellectual flight, does not increase our respect for his memory ; but Mr. Schmidt, whose philological tastes seem to be in advance of his scientific, seems to think it would be worth while to reconstruct the machinery, and play the little drama over again to a select audience. He admits the difficulties, both in following the original MSS. and in filling up some necessary lacunæ, but considers the labour would be well spent, since it would illustrate in a most realistic manner the amusements of the ancient inhabitants of Alexandria.

\section{THE SITUATION OF OPHIR.}

A REUTER'S correspondent has had an interview A with Dr. Carl Peters on the subject of the re-discovery and identification of the ancient gold-bearing site now so well known by the name of Ophir. According to the eminent German traveller, this much discussed locality is situated on or near the Zambesi river, and he is confident that the theories which would place Ophir either in India or in Arabia are both wrong. Dr. Peters is not the first who has convinced himself that Ophir lay somewhere on the east coast of Africa, for the late Mr. Bent and other recent writers believed that they had identified the famous emporium whence Solomon, the king of Israel, obtained gold for the temple at Jerusalem. It must, of course, be admitted that remains of extensive gold workings undoubtedly exist in the locality, and that these possess considerable antiquity cannot be denied. It is, however, open to discussion whether the ruins and workings are "of undoubtedly Semitic type," and also whether the emblems which Dr. Peters identifies as phallic are really connected with "the ancient Semitic sun worship." Until Dr. Peters distinctly states his case in print, and gives his reasons for the faith which is in him, we can do little more than point out that up to the present the theory which would place Ophir, or Aphar, or Sôphir (I Kings ix. 28; x. I I 2 Chron. viii. I8; ix. Io) the great metropolis of the Sabeans, which is described in the "Periplus" attributed to Arrian, on the Gulf of Akabah, has not been disproved. The theory which would place Ophir in India, on the banks of the Indus, has much in its favour, and when it is remembered that the precious stones and almug trees, which are mentioned with the gold of Ophir, are the peculiar products of India, it is a little difficult not to accept it without more ado. On the other hand, the apes and peacocks (or parrots as some would translate the word tukkiyyîm), which were brought to Solomon from the neighbourhood of Ophir, indicate that its site was nearer Palestine than India; for it is well known that peacocks would not survive a long voyage which must have lasted several months, and must also have been made in an open boat. The fact is that many places can produce, and must always have produced, gold in great abundance, and we are driven irresistibly to the conclusion that more than one place bore the name of Ophir.

It is not necessary for the Ophir, whence Solomon obtained gold, to have been situated as near as the northern end of the Red Sea, for it is most likely that the seamen, who traded through Hiram, with him obtained the goods which they had to sell from the larger boats which sailed through Bâb el-Mandeb either to India, or to ports on the north-east and east coasts of Africa. Meanwhile Dr. Peter's claim to the discovery of the Ophir mentioned in the Bible will evoke consider-

NO. 1.574 , V'OL. 61 ] 
able interest, and we must hope that he will lose no time in bringing before the world the important facts which he must have collected, and the evidence which would connect the phallic rites and worship of the Northern Semites (which have been so carefully described by old John Selden in his "De Diis Syris") with the nature worshippers on the east coast of Africa.

\section{FORMALIN AS A PRESERVATIVE.}

$\mathrm{A}^{\mathrm{L}}$

THOUGH as a preservative medium for perish able zoological specimens, formalin has scarcely realised all the expectations entertained on its introduction, yet there can be little doubt that it has a great future before it, and that for certain purposes it is likely to prove invaluable. It has, however, many undoubted disadvantages; and in the minds of some museum officials these disadvantages appear to outweigh its manifest valuable properties, so that an unfavourable opinion is entertained of it in generai. On the other hancl, those who weigh more carefully the pros and cons, realise that, under proper conditions and restrictions, its value is really very great.

As regards its disadvantages, it must be admitted that it is unsuitable for the permanent preservation of specimens that are likely to be manipulated, as not only are its effects on the hands of the worker most unpleasant, but in many cases it renders the tissues of the specimens themsclves so hard that they are practically unworkable. Then, again, it is quite unsuited for all specimens containing calcareous matter, such as molluscs, echinoderms, and crustaceans; while unsatisfactory results appear to have been obtained in the case of certain insects and myriapods. Mbreover, it does not seem to be well suited for the preservation of reptiles; and it is said to deteriorate the colours of bird-skins.

Turning to its advantages as a permanent preserving fluid, it is acknowledged to be unrivalled for specimens of watery and "flabby" animals, such as jelly-fish, rendering them more coherent and less likely to disintegrate than any other known medium. Apart from this group, it does not, however, appear to be at present used to any great extent in the exhibition series in the British Museum; although we have reason to believe that its possibilities are occupying the serious attention of the officials. In the series of worms, all the more valuable specimens that were received in formalin have been transferred to spirit, and only the commoner forms left in the original medium. Of the six specimens of eggs, embryos, and larvie of Lepidosiren paradoxa recently added to the exhibition series from Mr. Graham Kerr's Paraguay collection, three are in alcohol and three in formalin; the latter having been sent home in that fluid, and it being thought not advisable that the medium should be changed. If these six specimens are carcfully watched, they will afford a test-case of the comparative value of the media. At present, we believe, none of the exhibits in the "Index Museum" are in formalin.

For sterilising freshly killed specimens of niammals and birds, as well as eggs, that have to be sent some distance to a museum in the flesh, there can be no doubt that formalin is invaluable. And it is no less valuable to the field-collector of mammals, not only on account of the small bulk a sufficiency of the fluid occupies, but also from the marvellous preservative power of the fluid itself. According to $\mathrm{Mr}$. O. Thomas (who reports very favourably of it for this purpose), commercial formalin, which is itself 40 per cent. under proof, must be diluted with no less than twenty-five times its own bulk of water before use. Moreover, whereas when mammals are preserved in spirit it is necessary to allow a very large amount of fluid to each specimen, when formalin is employed the vessel may be crammed as full as possible with specimens, which are preserved without exhibiting the slightest traces of putrefaction. When received at the British Museum all such specimens are, however, immediately transferred to alcohol, on account of their unsuitability for handling when in the original medium.

The foregoing instances suffice to show that for certain specific purposes formalin has advantages as a preservative medium not shared by alcohol. But, as many of our readers are aware, another application of formalin has been recently proposed by Dr. (x. de Rechter, of the Brussels University, who, in the twelfth volume of the Annales de Institut Pasteur (1\$98), has advocated the use of currents of formalin vapour for the preservation of animal specimens. The advantages claimed for this method are that it preserves the specimens in practically the same condition as they were left at death; the tissues not being hardened, while hair and feathers are uninjured alike in texture and in colour. Experiments in this method have been recently undertaken in Mauritius by $\mathrm{Mr}$. Camille Sumeire, of the Albion lock Company, who has constructed an apparatus on the general lines of one suggested by Dr. de Rechter, in which specimens can be subjected to constant currents of formalin vapour. And it appears froin an illustrated report published in the Bulletin de la Societc' Mídicale di Dlle Maurice for July I8, that the results of these experiments have proved eminently satisfactory.

A freshly killed guinea-pig placed in the apparatus for a period of twenty days was found to be in a perfect state of preservation, and when exposed in the open in the museum for a further period of eight days, was likewise found to be intact. Noreover, a culture of bacilli exposed in the apparatus at the same time as the guinea-pig was found to have become completely sterilised.

As was well remarked by Ir. de Grandprè, superintendent of the Port Louis Medical Museum, the potential advantages of such a method of preservation are likely to prove very important. And it is urged that the process may be specially valuable in cases of suspected poisoning, as bodies can be preserved for any length of time in a state suitable for examınation. From a natural history point of view the invention has likewise almost unlimited possibilities; and Mr. Sumeire hopes to be able shortly to supply the museums of Europe with examples of the anımals of Mauritius as fresh as when alive, instead of in the condition of ordinary spiritspecimens. Indeed, negotiations are already opened with the director of the Paris. Museum for the transmission of such formalined specimens to the institution under his charge. We wish all success to the new venture.

R. I..

\section{A GREAT SALT LAKE PROBLE.H.}

A $N$ alluring possibility has for a long time attached itself to the economic resources of Cireat Salt Iake, in the Western Inited States, in the way of establishing in its waters, as permanent residents, forms of marine life of commercial importance. The inited States Fish Commission recently made an examination of the lake with a view to determining the feasibility of such a plan. The work was undertaken by Mr. H. F. Moore, of the Commission, who finds in the peculiarly interesting conditions which prevail in this unique body of water a decisive answer.

Crustacea, insect larvie, and the lower plant-life abound in its fresher parts, but for the ordinary inhabitants of the sea the salinity is much too great in the main body of the lake. (ireat Salt Lake is a remnant of the pre. historic Lake Bonneville, which was fresh, or nearly so, until its drainarre basin became isolated by climatic and NO. I 574 . VOL. 6I 